This item was submitted to Loughborough's Research Repository by the author.

Items in Figshare are protected by copyright, with all rights reserved, unless otherwise indicated.

\title{
Saying it with feeling: analysing speakable emotions
}

PLEASE CITE THE PUBLISHED VERSION

http://dx.doi.org/10.1177/0018726708088997

\section{PUBLISHER}

Sage Publications / @ The Author(s)

\section{VERSION}

AM (Accepted Manuscript)

\section{LICENCE}

CC BY-NC-ND 4.0

\section{REPOSITORY RECORD}

Coupland, Christine, Andrew D. Brown, Kevin Daniels, and Michael Humphreys. 2019. "Saying It with Feeling: Analysing Speakable Emotions". figshare. https://hdl.handle.net/2134/14839. 
This item was submitted to Loughborough's Institutional Repository (https://dspace.lboro.ac.uk/) by the author and is made available under the following Creative Commons Licence conditions.

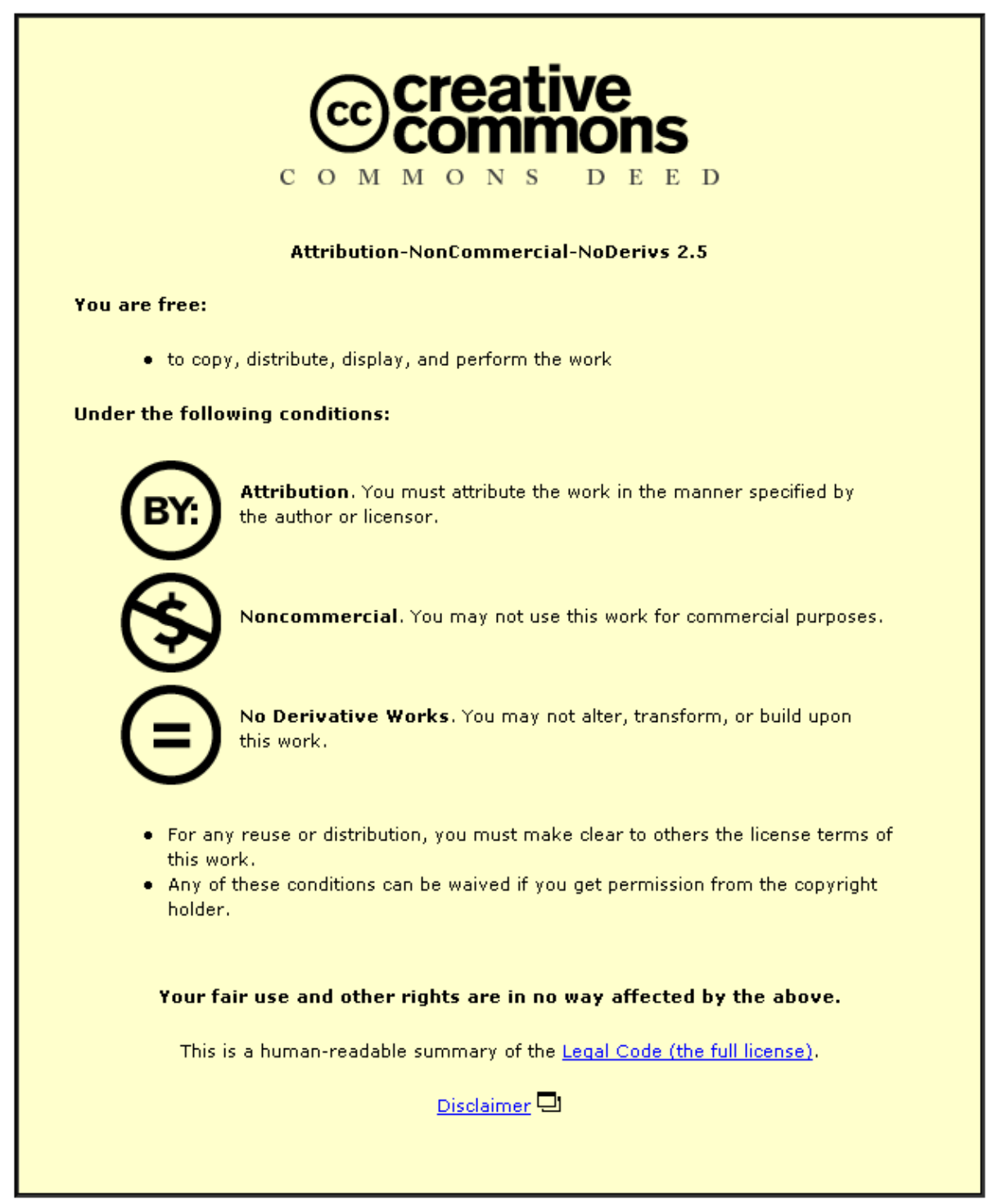

For the full text of this licence, please go to: http://creativecommons.org/licenses/by-nc-nd/2.5/ 
Coupland, C., Brown, A.D., Daniels, K. and Humphreys, M. (2008) Saying it with feeling: Analysing speakable emotions. Human Relations, 61(3): 327-353

\begin{abstract}
In this article we examine accounts of emotional experiences in one organization. Drawing upon data from inter views across a range of employees, we analyse aspects of emotion, identity and power. Adopting a constructionist perspective we use a method of discourse analysis to analyse how participants constructed emotions according to tacitly understood rules regarding appropriate emotional displays. These rules were made visible through an examination of the participants' positioning strategies as they described emotional experiences. Our findings suggest that, rather than an institutionally held level of appropriate articulations of emotionality, there was a role-related, socially located rule system linked to separate categories of teachers, managers and administrative employees. The contribution of the article is threefold. First, we use in-depth case data from 44 semistructured inter views to analyse how teachers and managers/administrators in a UK-based further education (FE) college constructed emotions according to certain rules (informal norms) regarding appropriate kinds of emotional displays. Teachers acknowledged and upgraded labelled emotions, while managers and administrators denied and downgraded accounts of emotional experiences. Second, we discuss the implications of talk about emotion for the (re)production of teachers' and managers/administrators' work identities. Third, we consider how people's talk about emotions was bound-up in relations of power.
\end{abstract}

\title{
Introduction
}

In this article, we examine individuals' accounts of emotional experiences at work. While emotion in organizations has become an 
area of sustained interest over recent years (Ashkanasy et al., 2000; Bolton, 2000; Briner, 1999; Callahan, 2004; Fineman, 1993, 2000; Hochschild, 1983), the socially constructed nature of structures, processes and practices of emotion in organizations remains unclear (Domagalski, 1999). Also, there have been multiple calls for methodological and theoretical ingenuity in order to provide finergrained studies of how people at work assemble and deploy emotions (Briner et al., 2004; Fineman, 1993; Hopfl \& Linstead, 1997; Patient et al., 2003). The contribution of this article is threefold. First, we use indepth case data to analyse how teachers and managers/administrators in a UK-based further education (FE) college constructed emotions according to certain rules (informal norms) regarding appropriate kinds of emotional displays. Second, we discuss the implications of talk about emotion for the (re)production of teachers' and managers/administrators' work identities. Third, we consider how people's talk about emotions was bound-up in relations of power.

Predicated on an understanding that the construction of emotional meaning is embedded within social contexts (Fineman, 2000; Newton, 1995), and that language is a vehicle for the construction of meaning (Fairclough, 1995; Waldron, 2000), we explore how people draw upon the language of emotion to perform discursive social acts. Previous public sector studies in this area include Howard et al.'s (2000) work on the New Zealand Police Force, Zembylas' (2004, 2005) ethnographic studies of teaching, and Tracy's (2004) analysis of correctional officers. We build on this research to analyse how descriptions of emotional experiences can be regarded as resources that may be utilized flexibly to 'manage' their identities. Paying attention to emotions as socially sustained practices enables us to examine 'appropriate' communication rules and the material consequences of these rules. We consider how the members of our case organization attended to, and drew upon, local systems of rights, obligations and role-related resources that both enabled and constrained their ability to talk about emotional experiences (Harré, 1986). We suggest that accounts of emotions exist in reciprocal social exchanges and thus that local language practices and the prevailing local moral order impinge heavily on individuals' expressions of emotion.

Despite Harré's (1986) initial signalling that this was an important approach to understanding emotion 20 years ago, it has not been built upon extensively through empirical study. We intend to begin to remedy this and propose that analysis of emotion language in context 
can help efforts to surface and to analyse the rules (informal norms; see Goffman, 1959; Strauss, 1959) which shape linguistic acts.

\section{Emotion, power and identity}

While some theorists continue to maintain that there is an 'empirical neglect of emotion in organizational studies' (Sturdy, 2003: 86), over the past two decades there has been a clear trend towards developing and exploring an emotion-centric agenda in organizational contexts (e.g. Bolton, 2000, 2003; Fineman, 1993; Hochschild, 1979, 1983). Considerable work has been undertaken focused on feelings in organizations (Albrow, 1994), on organizations as sites which feature love, hatred and passion (Fineman, 1993), and which explores the commercialization of actors' emotion management skills (Hochschild, 1979, 1983). Our study draws principally on constructionist approaches which suggest that emotions are 'strategic evaluational claims associated with local meaning systems, based on cultural cues or precepts' (Barbalet, 2001: 23) and, at least at one level, emotions are appropriately conceived as 'linguistic phenomena' (Denzin, 1984: 57). This symptomizes an acceptance that 'organizations are emotional arenas' (Fineman, 1993: 8, 31) and are fundamental to an appropriate understanding of the complexity of human relations (see Vince, 2006).

Taking as our starting point Goffman's $(1959,1967)$ argument that social rules influence the processes by which people actively manage and express emotions, our particular interest is in actors' accounts of their emotional performances at work. These performances are aspects of inter- active meaning-making processes in organizations that act to bind individuals together (Gabriel, 2000). Multiple kinds of emotional performances have been identified in work organizations. Bolton (2000), for example, has distinguished four distinct types of emotion management: 'presentational' (emotion management according to general social, 'rules'), 'philanthropic' (emotion management given as a 'gift'), 'prescriptive' (emotion management according to organizational/professional rules of conduct) and 'pecuniary' (emotion management for monetary gain). Social actors, argues Bolton (2000: 160-1), are able to draw on different sets of feeling 'rules' in order to match feeling and 'face' with situation: that is to 'effortlessly move from one performance to another, continually criss-crossing the often invisible boundaries between the public and the private worlds'. We build on this stream of research, arguing that the 'rules' which inform 
presentational emotional performances may differ between groupings within an organization, and that these performances are also political acts (see Barley \& Knight, 1992).

One particular focus for theorists of emotion has been the 'context rules' (i.e. emotion codes that fit a time and a place) that influence emotional displays and people's descriptions of them (e.g. Clark, 1990; Ekman \& Davidson, 1994). Hochschild (1979), for example, uses the phrase 'feeling rules' to refer to socially shared (though often latent) understandings regarding emotions while Rafaeli and Sutton (1989) make use of the notion of 'display rules' (see Fineman, 1993). The results of this stream of research imply not only that 'emotion is a necessary link between social structure and social order' (Barbalet, 2001: 27), but that the display rules which influence emotional performances facilitate task effectiveness by making social interactions more predictable (Ashforth \& Humphrey, 1993). To be able to articulate particular emotions is intimately connected with the claimed moral right to do so (Stenner, 2005). Emotion words are used rhetorically to construct events in or out of the ordinary rather than derived from internal states (Locke, 2002; Sarbin, 1989). Thus to describe oneself as angry or anxious is to deploy an available discursive resource to describe a social response in a social situation that performs a particular function (Stenner, 2005). Much attention has been directed to the attempts made by senior managers in organizations deliberately to structure social guidelines that explicitly regulate the 'emotional labour' of employees, requiring them to suppress, hide or manipulate their own feelings in work situations (Bolton, 2000, 2003; Callaghan \& Thompson, 2002; Sutton, 1991).

This suggests that '. . . emotions must be understood within the structural relations of power and status that elicit them' (Barbalet, 2001: 26). Several corollaries relevant to our study follow from this. First, there is a reciprocal relationship between emotion and social context such that emotions can serve to reinforce or transform social structures and power relations (Williams, 2001). Second, while 'greedy' organizations (Flam, 1993) may attempt to control and commodify emotional elements of organizational actors' lives, such efforts may be met with resistance (Callaghan \& Thompson, 2002). Finally, we should note that although rules, scripts and norms (Strauss, 1959) are an everyday part of organizational existence, 'the deliberately formulated rules of an organization only form part of a given reality' (Mills \& Murgatroyd, 1991: 22). In work situations there are often 
'unmanaged spaces' (Gabriel, 1995), 'back regions' (Goffman, 1959) or 'zones' (Fineman, 1993) where people may exercise idiosyncratic discretion - to resist, misbehave, or indeed to promote an organization's official line (Bolton, 2003: 297).

As with much of the burgeoning literature on the linguistic construction of emotions, we take as one of our core themes the linkages between identity and emotion work (Fineman \& Sturdy, 1999). It is recognized that often people construe their identities with an explicit emotional component. We draw upon Wittgenstein's (1953) description of the emotional self as a set of sited language games and Lyotard's (1984) notion of a practical self that is interactionally at stake rather than philosophically taken for granted in order to focus upon indexical and reflexive features of linguistically accomplished identities. Rather than 'social dopes' or 'calculating intellectuals', our view of social actors is that they are able to exercise creative potential within the constraints imposed by social structures. Identities, we maintain, are practical projects (discursive accomplishments) of everyday life, and, complementarily, employees are active, skilled emotion managers (Bruner, 1990; Callaghan \& Thompson, 2002; Sutton, 1991). One import- ant contribution of this article is to show how accounts of emotional experiences are deployed to sustain and signal acceptance of organizational practices (mostly by managers and administrators) and contest and resist (on the part of teachers) their lot.

To summarize, our principal contributions relate to illustrating how individuals draw on organizational interests in order to deny, minimize, or legitimate individually experienced/expressed emotions. We show how these interests are drawn on in different ways according to the rolebased rule system that operates within a particular context (see Waldron, 2000), and how these position individuals' social identities and relations between different social identities. No study of emotion can be entirely unproblematic, and as authors we, of course, acknowledge that in the re-creation of these accounts we are reproducing suppressed, neutralized and contained emotions expressed by members of the organization (Hopfl \& Linstead, 1997). The remainder of the article consists of an overview of our method- ology including a description of the research context, an analysis of our primary data, and a discussion of our principal findings.

\section{Methodology}


Our study has been conducted from a constructionist perspective using a discourse analytic methodology derived in the main from discursive psychology (Antaki et al., 2003). This is a broad perspective characterized by multiple internal debates regarding different aims and styles of work among scholars (e.g. Schegloff, 1997, 1998; Wetherell, 1998). Our particular interest is in how people talk about emotions, their own and others, and how these may be regarded as intelligible social performances (Edwards, 1999; 2001). In keeping with other research and theorizing our analysis centres on talk about emotions to analyse how (what are presumed to be) prior notions of emotion are attended to, categorized and managed. We analyse what people are doing when they describe a particular emotion, focusing on their emotion language as a rhetorical performance - 'a nexus of action and accountability' (Edwards, 1999: 281).

The research context

Located between the school and higher education (HE) sectors (Lumby, 2003) further education (FE) in the UK, the 'Cinderella of the education service' (Baker, 1989: 3), has seen more radical change and development over the last few decades than any other sphere of educational provision (Merrill \& Hyland, 2003). The most radical of these changes occurred in 1993 with incorporation, which meant that FE colleges became corporate institutions, many of which subsequently suffered from financial mismanagement. Throughout the FE sector lecturers' teaching hours had increased by a third or more with the abolition of the 'Silver Book' agreements (Kerfoot \& Whitehead, 1998: 441), and there had been several rounds of compulsory redundancies (Shain \& Gleeson, 1999). The minimal resistance to these radical management reforms has been attributed to the fear of job loss among the FE workforce (Lumby, 2003; Shain \& Gleeson, 1999) and the weakened role of the college lecturers' union (NATFHE), which lost a bitter industrial dispute over conditions of service in the mid-1990s (Burchill, 2001). Edward et al. (2007), in their study of 24 colleges raised serious questions about the pace of such policy-led change arguing that the plight of FE lecturers is a significant example of 'professionals' responses to turbulence' in the public sector, and that research is needed urgently in order that policy-makers can 
consider the impact on staff. As Humphreys and Hoque (2007: 1201) point out, 'This is hardly an environment in which a participative approach to management could be expected to have flourished'.

Our case study institution was, in many ways, typical of those recovering from the 'series of college "failures" . . . through the 1990s' (Goddard-Patel \& Whitehead, 2001: 181) in that post-incorporation it had suffered a 'breakdown in staff/management relations, [and] the removal of challenging governors and irregularities in the conduct of the governing body' (Goddard-Patel \& Whitehead, 2000: 196). After severalreorganizations, changes in management and merger the socalled 'new' college had been established on three geographically separate sites. The merged college, the mission statement of which was 'success through quality, innovation and diversity' had, in total, some 32,000 enrolled students, 3500 full-time and mostly 16-18-year-olds, and 28,000 adult part-timers. This large and diverse general purpose college was managed by a team of senior staff called the 'directorate' led by a Principal (Chief Executive Officer) and a Deputy Principal (the Director of Finance), two 'Executive Directors' responsible for HRM and quality systems, and two Vice Principals responsible for student services and management information and Estates. Most staff were, how- ever, full-time lecturers (some of whom had administrative responsibilities), and professional administrators, organized into multitier site-specific hierarchies.

\section{Research design}

We regard the construction of accounts of emotional events as temporary and context relevant, thus the language used in their construction features as a resource of culturally available linguistic tools. The 'linguistic turn' in the social sciences has led to recognition that language is both descriptive and in part constitutive of what were once deemed to be wholly psycho- logical phenomena (e.g. Potter \& Wetherell, 1987). A huge range of interpretive work has been conducted using a multitude of discursive methods (e.g. Brown, 2005; Coupland, 2002; Learmonth, 1999; Watson, 2000). There has in particular been an increasing preoccupation with analysing how discoursal practices contribute to the reproduction or transformation 'of existing social and power relations' (Fairclough, 1995: 77). Our position assumes that discourse - language use in speech and writing - is a form of social practice that both shapes, and is shaped by, social structures. These processes of discursive constitution, though appearing naturalized, 
are not ideologically neutral so that the unequal relations of power that they repro- duce are characteristically opaque to participants (Van Dijk, 1997). Following Craib (1997) we do not deny our own subjectivity as researchers, and of course recognize that our 'results' are contestable social constructions. We note also that research methods, including discourse-analytic approaches, construct 'a particular picture of humans' (Tseelon, 1991: 313).

Data collection

This research was conducted during the summer of 2004. Access to the college was granted by the senior management team. Notices were 
distributed asking for people to volunteer to take part in a study of workplace stress and emotion and all employees of the organization were invited to participate. Semi-structured interviews were conducted with self-selecting participants who were employed across a broad range of positions in the organization. The interview consisted of openended questions surrounding emotional experiences, such as anger and anxiety during which the partici- pants were encouraged to follow and develop issues of concern as they arose. A total of 44 interviews of approximately 60 minutes duration were conducted, each of which was audio-taped and fully transcribed using a simplified notation system (Silverman, 1998). Of the 44 volunteers inter- viewed, 26 were women, 28 were involved in teaching activities, 6 in adminis- tration, and 10 were managers. The managers' group was constructed through their self-labelled positioning as 'manager' when asked for their job title and career history. The mean age of the sample was 46 years (range 22-60 years). On average, members of the sample had been working in their current role for 8 years (range 0-32 years), and had been working at the institutions that comprised the new College for 11 years (range 0-30 years).

\section{Data analysis}

In analysing our data we utilized an eclectic mix of discursive approaches which have been employed by other researchers to examine 'internal' constructs such as emotions and identities (e.g. Edwards, 1997; Harré, 1986; Howard et al., 2000; Potter, 1996; Potter \& Wetherell, 1987; Widdicombe, 1998). Consonant with approaches dominant in discursive psychology we focused on how emotion labels and associated descriptions were invoked by people, and what kind of work such invocations performed (Edwards, 1999; see Antaki et al., 2003; Schegloff, 1997, 1998; Stokoe \& Smithson, 2001). We operated with an understanding that we were examining situated communication practices as socially active in patterns of interaction (Coupland, 2001). Specifically drawing on Harré (1986) we attempted to analyse: 1) the repertoire of language use associated with emotion-talk in the transcripts; 2) the social and discursive functions which the emotion talk enabled; and 3) the rule systems in use regarding 'appropriate' emotional expression. The transcripts were read several times, and focal 
points of interest were noted. Over time this led the research team to attend to associations between the professional identities of participants and their accounts of emotional experiences. Our preliminary analyses were then presented to colleagues at seminars, and in the form of a widely circulated draft manuscript, and this article is informed by the comments that we received While ours is a study of reconstructions of past emotional experiences, the accounts that we collected were, of course, new productions, that is, in the research interaction new emotional constructions were generated by interviewees for us, the researchers. This was a design feature of our research methodology. It may have been that the interview situation functioned as an opportunity for participants to develop new ways of expressing emotions through the re-labelling of feelings and the denial of labels through positioning in the interaction. The research interview is an interpersonal encounter in an institutional setting, though perhaps on the 'fringe' or boundary, and the accounts we collected may be considered as being 'about' rather than 'of' the organization. From our social constructionist viewpoint, we seek to explore social forces that account for phenomena such as emotion, and attend to the social and discursive elements of its construction.

During our readings of the material and subsequent analysis, distinct role-related themes surfaced. This is not to suggest that clearly defined groups had exclusive use of particular ways of describing emotional experiences in the organization. Evident, rather, were patterns of 'tendency' which merited further investigation. The analysis which follows suggests that, instead of an institutionally held level of appropriate articulations of emotionality, there was a role-related rule system. This has been made visible through an examination of participants' positioning strategies as they described emotional experiences. Three distinct groups' strategies have been identified as linked to individuals' work roles as teachers, managers, and administrative employees. Teachers tended to articulate, acknowledge and upgrade labelled emotions; managers and administrators tended to deny and downgrade accounts of emotional experiences in complex ways.

\section{Re-labelling - downgrading and upgrading}

Downgrading

Managers and administrative employees largely downgraded 
or denied being emotional subjects. This was possibly to be expected from managers as much has been written about their role as involving the control of emotion: 'the manager's emotional labour also involves regulating feelings, his own and those of other people' (Hochschild, 1993: xi). A simple example of re- labelling follows in an extract from an interview with a member of the management of the organization. This was given in response to being asked for an example of an incident that made the participant angry.

Extract 1

I'm not the kind of person who gets angry. It's not an emotion that I

really have a great deal of experience of.

(Male manager: 4O SM)

Similar techniques of re-labelling and subsequent mitigation were evident in administrative employees' talk, an example of which is given in extract 2 .

\section{Extract}

2

I don't think sadness really is an emotion I'd identify with very much. (Female administrative employee: $2 \mathrm{KA}$ )

\section{Upgrading}

In marked contrast, a response to a question about anxiety illustrates what was a typically upgraded construction of emotion from the teaching employees. In the following extract there is a spontaneous definition of what anxiety means to this person. It is constructed as very close to the speaker, with colourful language and powerful expressions of feeling. In addition, causal elements are claimed personally.

\section{Extract}


Shit this looks really bad, ... am I going to be found out, ... is this mistake of mine going to be exposed . . . God what if the results this year are terrible - every year you have a semi-panic attack.

(Female teaching employee: 3Iz)

Another example of an emotion description from teaching employees included an account of an emotional outburst:

\section{Extract}

4

... after the initial shouting and screaming and stamping my feet I've just got on and prepared a load of work for them ...

(Male teaching employee: 5DC)

This contrasts sharply with managers and administrators whose descriptions of emotion did not include claimed emotional outbursts. In this instance, the emotional reaction is described through 'out of control' behaviours such as shouting and stamping. We suggest that the analysis of different vocabularies in descriptions of emotional experiences makes visible systems of obligations and criteria of value that is judgements regarding appropriateness of behaviour (Harré, 1986). The question whether an emotion is justified does not turn on an issue of fact. Rather, whether it is justified is about 'reasonability'. From the above two extracts we can see that emotional behaviour is deemed reasonable and justified by teachers in the organization. Harré (1986) argues that two social matters impinge on personal experience/expression of emotion - local language and the local moral order. We argue that what is made visible here is a moral order that sanctioned teaching employees' accounts of their behaviour in emotive terms. The well-understood increasingly unreasonable conditions of their work, as they conceived them, provided a context in which talking about being emotional was 'appropriate'. This is in keeping with Fineman and Sturdy's (1999) claim that imprints of emotion protocols regularize appropriate conduct, in this instance as differentiated actors within the organization. 
Our participants' responses to questions about accounting for emotional experiences included a mixture of mitigations for claims to having been emotional at work. Mitigations in this sense refer to the ability of participants to describe emotional experiences while counteracting the potentially negative consequences that these descriptions may have had for their professional identities. Potter and Wetherell (1988) suggested that mitigations may be produced at the same time as other claims with negative potential and function to reduce the negative force of what is being said.

It appears that it was not deemed appropriate, in the research interview at least, for any of the organization's members to deny emotionality directly. It is, though, possible, that our interviewees were engaged in a 'new' (for them) way of 'doing' emotionality for the purposes of the interview. Talking with others about emotional experiences may have led interviewees to redefine emotional material (Fineman, 1993). It may be that ways of denying emotionality further distance some speakers (managers and administrators) from those that do claim emotional experiences (teachers). How this was carried out is explored in the following extracts. It is evident that the ways interviewees used emotion-laden words had implications for behaviour and their understandings of social context. For the interviewees, emotion talk formed part of their vocabulary of appraisal and criticism, and sometimes more specifically moral criticism (see, for example, Bedford, 1986). In extract 5, which is taken from a manager's response, although the 'depression' is claimed then mitigated, its 'cause' is located with other employees' behaviour.

\section{Extract}

5

I feel depressed when people don't pull their weight, perhaps that's . . . but I don't really do depression, so I wouldn't say that depressed was something I felt. I feel mildly irritated and peeved and let down and all those 
other sideways bits.

Another discursive resource which was drawn on in order to deny a claim to emotionality was the construction of proximity or distance between the speaker and the emotions being described. This is illustrated in extracts 6 and 7. We suggest that one key way this (distancing) may be accomplished was by expressing emotions on behalf of the organization or other groups of people. These categories of self and other in the form of the organization or the College, for example, then functioned as resources to render an account of individually held emotionality at an 'appropriate' level through constructing distance from the emotion expressed.

Extract 6

I have to say not in my present role I don't have any anxieties. If I have any anxieties at all they're not about me but about the organization

... So my anxieties in my present role only focus on the fact that I feel saddened and anxious that we may not be able as a college to move forward ...

(Female manager: 5P)

\section{Extract}

7

I don't have many things that make me feel that way but I think I get saddened when I see education in general battered by the press and told what we are not doing when I know what tremendous work so many people do actually give. I think that saddens me.

(Female manager: 6R)

Furthermore, when managers described feeling emotional on behalf of the organization, their constructions of causal factors were drawn from beyond the confines of the organization. Thus they constructed the situations as being beyond their control, and the events as occurrences 
for which they could not be held accountable. It may have been that to talk of uncontrollable, emotion-evoking, events within the organization would have presented too great a threat to their role as managers. This is in keeping with findings from other studies of emotion (e.g. Harré, 1986) particularly where others are represented in public performances of feelings (Vince, 2006).

This type of causal inference was not drawn on by any of the administrative employees. However, distance was constructed through role- appropriateness in that the relevance of an emotional response was questioned by evoking and establishing hierarchy - that others in the organization may be more emotionally involved due to their positions and responsibilities. This point is illustrated in extract 8 , which has been taken from an interview with an administrative employee who was responding to a question about feeling sad or depressed.

\section{Extract}

8

It's more annoying really [asked about reaction]. No I just get annoyed, you know . . . I don't get paid that money to chase around so leave it because the buck isn't going to fall on me at the end of the day.

(Male administrative employee: 7 pca A)

A further resource drawn on by administrative employees was a claim to professionalism that questioned whether being emotional in the work place was appropriate. An example of this is provided in extract 9 , taken from an interview with an administrative employee who had just described a 'rare' instance of losing her temper.

\section{Extract}

9

I think it is unprofessional, I think it is unprofessional

I think you should be able to discuss your problems.

(Female administrative employee: 8 JBA) 
This helps to illustrate the evaluative nature of emotion discourse - both of one's own and others' behaviour. It is as if by describing an occasion on which s/he was emotional the speaker is then able to occupy a higher moral ground. Distance is created between the interviewee and lack of professionalism (i.e. a potentially damaging, uncontrolled, emotional outburst), by constructing the self as a subject who knows better. Thus, one function of emotion descriptions may be judicial, establishing and policing a repertoire of acceptable emotional behaviours (Bedford, 1986). Individuals' capacities to express emotions are, in large part, culturally based, contingent upon their understanding of certain norms, rules, mores, customs and traditions, and their local interpretation of specific matters using these cultural reference points (Armon-Jones, 1986). This does not mean that professional workers will always behave, or describe themselves as having behaved in, an 'appropriate' manner by drawing on a professional identity. Rather, the stocks of knowledge, skills, and traits associated with their professional identities may be regarded as resources which provide opportunities for (in our case emotional) distance when required. This suggests that an analysis of the different uses of vocabularies associated with accounts of emotional experiences at work needs to involve careful attention to local systems of rights, obligations and what is deemed to be appropriate behaviour. It is not simply that emotions cannot be studied without attention to the local moral order (Harré, 1986). Rather, that moral order and measures of judgement become visible through an examination of people's emotional vocabulary.

Role and identity

Subjectively construed identity is a key resource which speakers draw on to deny, claim, or in other ways position themselves with respect to emotional experiences. For example, in extract 10, a manager uses a 
generic cultural understanding of identity types ('sorts') to make 'plausible' claims about her behaviour. Identity is drawn-on in this instance in order to perform social functions connected to the denial of emotional responses to organizational issues.

\section{Extract}

10

I get depressed when I look at some of the policies that come out of national government or even when I say depressed I'm not the sort of person who gets depressed in the sort of clinical sense but if I just use the word saddened rather than depressed.

(Female manager: 7S)

In everyday talk simple and explicit claims are made based on category membership features (Sacks, 1992). However, claims may also be made regarding former or implied identities which are made salient in emotion- descriptions. One example of this is provided in extract 11 which is taken from an interview with a member of the management team, illustrating a combination of the emotion rules and making explicit in particular their judicial nature. This has been taken from a response to a question regarding a time when the participant was angry.

\section{Extract \\ 11}

I suppose what I think though is that sometimes as a teacher you play emotions and you sometimes portray anger when in fact there isn't any anger deep down but it's the outward expression of perhaps frustration and so some of my colleagues might say I get angry but I wouldn't describe it that way.

(Female manager: 8T)

This response came some way into the interview and followed an earlier description of the manager as a former teacher. Sacks (1992) has examined how warrant to talk about rights 
and obligations of a social category (e.g. teachers) is itself worked up in talk. By claiming previous membership of this group warrant is constructed to talk knowledgeably as a former 'insider'. Alternatively, the speaker may merely be claiming a skill left over from a former role. From a third viewpoint, we can say that this works to negate the emotional claims of another group who are employed in the organization, the current teachers. By suggesting that teachers 'play' emotions it constructs an emotion rule for the research interaction. As the speaker talks about this process it enables her to occupy another position. Distance is created by the 'knowing' subject who claims the emotional description as a performance while questioning emotional experiences of teachers by describing them as superficial (i.e. not 'deeply felt') performances.

Teachers' emotional displays are such a feature of the organization that it is deemed plausible by managers to suggest that they may be a performance. An example of a typically upgraded and embraced emotional experience is illustrated in extract 12.

\section{Extract}

12

The state of my staff room makes me very angry. The fact that I have to teach some groups that are very difficult and who are not interested in the subject that I'm teaching makes me very angry. The food that I'm given to eat at work makes me very angry. It makes me very angry that certain individuals won't listen to what I've got to say about the situation .. . like with the argument with my line manager, that made me extremely angry ... It makes me really angry that sometimes I have to teach a day where I start at half past eight in the morning and I don't get home until ten o'clock at night. That makes me really angry. 
It is not that we did not collect instances where administrators and management talked about their feelings merely that their descriptions were constructed in markedly different ways from teachers, and followed a different set of emotion-rules. In keeping with Harré (1986), who has suggested that the first step towards a more sophisticated theory of emotions would be to show how research priority must be given to obtaining an understanding of how various vocabularies are used, we regard these different strategies about emotion talk as important. The managers and administrators' positioning of themselves as dispassionate, and their resort to notions of 'professionalism', created a discursive opportunity (or requirement) for teachers to construct themselves as a distinct social group with a distinctive collective identity as passionate experiencers of emotion. In the following extract we examine how a member of the teaching staff dealt with these issues (specifically notions of personal identity, social identity and vulnerability), in the context of the workplace.

\section{Extract}

13

I think it's me I think I am I do take on board those things because ... I try so hard to do the right thing . . . and I think it's in my personality that I can cope with stress and strains to some extent, that's my Achilles' heel . . . It's a vulnerability I think a teacher is vulnerable.

(Male teaching employee: $16 \mathrm{kd} 5 \mathrm{pca})$

Here the speaker constructs a dilemmatic situation. There is a tension between constructing difficult times and coping heroically. The heroic individual identity is drawn on to indicate how the speaker is coping against the odds, even though he is a member of the category 'teacher' and thus 'vulner- able' (see Wainwright \& Calnan, 2002). Social roles 
and personal identity may be regarded as interaction resources which render an account plausible to a particular audience. The language of coping has relevance in a context of difficult circumstances in which talk of being emotional works as a supporting framework. The extract 'speaks' to a need for theorists to discard those theories which detach emotions from context and discuss them in the abstract, and to reconnect 'emotions' with the language of everyday life (Sarbin, 1986: 84-5).

In analysing our case data we have attended to emotional vocabularies and their conditions of use. In so doing we have sought to illustrate that emotional expressions are forms of action which play a strategic role (Hepburn \& Brown, 2001; Vince, 2006). Most particularly, we have been concerned to argue that sophisticated investigations of emotion must include an analysis of the social contexts in which they are displayed. Our primary concern has been to study the 'rules' governing talk about emotions and emotional displays that prevailed in the FE college. If all members of an organization were to construct rules similarly we could then argue for the existence of generic contextually relevant rules regarding when, and if, it is appropriate to speak and behave emotionally. In the organization that we investigated, however, we found that sub-groups of members drew on different discursive rule systems. Managers and administrative employees largely downgraded accounts of emotionality whereas teaching employees upgraded and constructed their accounts through expressive descriptions. Downgrading was achieved, in part, through constructions of distance between the speaker and the emotions being described. In terms of claimed identity, being a 'type' of person legitimized both unemotional and emotional claims. It is interesting to note, however, how claiming to be a 'kind' or 'type' of person may be combined with concepts of work role and broader social notions of professionalism. In the examples analysed, managers claimed mitigated emotion on behalf of the organization, administrative employees rationalized emotional accounts which might otherwise have been deemed inappropriate and teaching employees gave accounts which embraced emotionality. 


\section{Discussion}

In this article, we have examined accounts of emotional experiences as linguistic performances, and as discursive resources, which have implications for social identity, conflict and accommodation. The articulation of emotional states and behaviours in the workplace, we have argued, is an active influencing behaviour, a performance designed to persuade an audience. We have examined how identities were constituted, claimed, and drawn on, and the extent to which these were institutionally defined. The discursive approach that we have adopted assumes that while emotions are linguistic constructs, the discourses on which they draw are forms of power constituted by material relations (Hearn, 1993). That is, some organization members constructed themselves (and were constructed by others) as being materially in control of others' emotions, in the creation of others' fear, sadness, and anger through, for example, measurement, resource allocation, and re-structuring. These are points that we further elaborate in this discussion.

\section{Emotional performance}

Our participants' accounts of their emotions were strategically important, politically sensitive performances of their selves (see Patient et al., 2003). The teachers used emotive language in ways similar to the teachers who were participants in Hepburn and Brown's (2001) study. If emotions are signifiers of the goals that are valued (Ortony et al., 1988), and can be indicators of the importance that we attach to attaining specific goals (Archer, 2000), it may be that teachers' talk about their emotions was symptomatic of their concern to serve students well. This resonates with Zembylas's (2005) study of the emotional regime of a school in which teachers sought to produce a particular teacher-identity aligned with the students. Managers' and administrators' mitigated emotional accounts are also consonant with other studies 
which have suggested that managers tend to downgrade emotional experiences and to make mitigated claims to feel emotion on behalf of the organization (e.g. Hochschild, 1993). In our case, an understanding that they were responsible, to some extent, for the emotional welfare of other members of the organization, may have made explicit expressions of negative emotional experiences difficult for them. While the problems that senior staff face in talking about issues of emotion in the workplace have been noted (Hepburn \& Brown, 2001), less attention has generally been paid to the role and consequences of managers, and others, in constructing and maintaining emotional detachment.

One clearly important issue that surfaced in our study is that of the similarities between managers' and administrative employees' accounts of their emotional experiences. Could this simply be mimicry, identification with the prevailing regime, an attempt to lay legitimate claim to status and/or power, or some combination of these? Or, could the role of measuring others' (failing) performance through administrative procedures have rendered them in a position of reflected influence that required apparent detachment? Have the administrative members of the organization come to occupy a position akin to political advisers between back-benchers and senior politicians, or the doctor's receptionist located between patients and doctors - as buffers or gatekeepers? Other research has suggested that conforming to prevailing notions of what is it to be a professional is central to appropriate emotion management (Kramer \& Hess, 2002), and we propose that the role of administrative employees in monitoring, surveillance, and feedback to management had led to their acceptance and mirroring of those behaviours deemed appropriate in terms of emotional display.

Identity, professionalism and emotion 
The linguistic performance of emotion does important discursive work, with descriptions of past interpersonal encounters, and associated accounts of emotions, having implications for identities, statuses and roles. Emotions cannot be reduced to purely physiological or even psychological states but are aspects of the social self: 'Emotions are one of the ways a people, a class, a race, experiences itself and its age' and 'emotions conform to an age's forms of knowledge, its collective ways of seeing and interpreting self, others ....' (Doyle McCarthy, 1989: 58, italics in original). As our case illustrates, people may choose (emotional) display rules consistent with their professional identities through a selfpolicing of emotional conduct (Zembylas, 2005). There are at least two reasons for this, one primarily psychological, the other social and political, though these need not be mutually exclusive. First, emotional displays inconsistent with a professional identity may lead to feelings of inauthenticity between felt and displayed emotions, in turn leading to worsening well-being and interference with the cognitive and social processes that underpin work performance in teaching (see Ashforth \& Humphrey, 1993). Second, display rules may be chosen to advance the goals of the professional group, especially where displays of unpleasant emotions can be used to argue that a profession is enduring psychologically aversive states and so deserves further social recognition (Barley \& Knight, 1992; Hepburn \& Brown, 2001; Zembylas, 2005).

In a context of emotion-control dictated by a perceived need to be 'professional', the teachers dealt with what they described as intense pressures to perform by drawing upon explicit emotional language, and this constituted a strategy for coping (Harkness et al., 2005). It is important to note that they drew on emotive language use as a resource despite its potential costs (i.e. threats to their perceived professionalism, status, etc.; see Ashforth \& Humphrey, 1995). Indeed, the explicit use of emotional language may have become one of the aspects of their professional identity deemed salient in a 
research interview about stress and emotion. Increasing surveillance, heavy workloads, and pressure to perform according to new managerialist criteria have become part of the FE teachers' everyday experience of work. These practices are legitimized internally through manager and administrative relations, and externally through Government policy, media reports and construed public perceptions. The teachers were subject to irate and abusive students, and as the service providers of the organization they were focused on by significant others as non-deliverers and under- performers. ${ }^{1}$ Emotiondescriptions function in the context of our study to illustrate first, intolerable demands, second, to construct a professional identity which was marked out by an ability to construct oneself as emotional, and finally, to present a foil against which they (teachers) were able to present themselves as apparently coping despite the odds. This finding is of note in the context of Humphreys and Hoque's (2007: 1210) conclusion that, since incorporation, FE lecturers have 'indeed lost their voice' in terms of communication with senior management; we have perhaps highlighted a replacement instrument of articulation in their accounts of emotionality.

We argue, therefore, in contrast to Kramer and Hess (2002), the rules for masking negative emotions differ according to professional group. We contend that, in contrast to much of the literature which sets emotion in disadvantaged comparison to rational thought (Lutz, 1996), when articulations of emotional experiences are viewed as resources available to a particular group of people in an organizational context, identities that are marked as different through emotional expression become visible. This suggests that the other groups (managers and administrators) were 'acting out' a different conception of what it was to be 'professional', that is, one in which emotions were presented as controlled and described as relatively muted. This is consonant with Howard et al.'s (2000) study of police officers which found that their emotion talk was preoccupied with issues of control and order. Although evolving power structures may undermine the legitimacy of certain emotions, we propose (see Vince, 2006), in the context of our study, that emotional and political dynamics had been generated by these 
very conditions.

Power, control and resistance

The language groups employed reinforced identifications with new or old institutional structures. That is, the teachers had most power under the previous FE institutional regime. Their criticism of the new order through accounts of negative emotional experiences in the workplace indicated that they had much to lose (indeed, much that they had lost). This may symptomize a degree of identification with the old institutional environment of UK FE. Regular contact with older staff may account for the apparent 'fact' that even younger members of the profession seemed to have been socialized into thinking that there was a pre-'incorporation' 'golden age'. Managers and administrative employees, however, had most to gain from the new order, where power had been relocated in processes of management and budgetary control. For these groups, there were 'costs' associated with talking about negative emotional experiences within an organization for which they were responsible. That is, teachers' upgraded talk about emotions may be understood as symbolic acts of resistance against what they perceived to be an unreasonable, uncaring and unresponsive regime. Conversely, managers and administrators' downgraded emotion talk symptomized not only their acquiescence but active participation in a regime which they considered rational, efficient and (at least potentially) to offer opportunities for career advancement. In practical terms, it appears that the emotional discourses analysed in the college legitimated perceived poor work conditions and hours, preserving a status quo that satisfied managers and administrators rather than teaching staff.

Our research echoes that of Brown and Humphreys' (2003) account of the FE sector since incorporation. Their findings suggest that while senior managers tend to tell 'a narrative of epic change (in which they cast them- selves as adept managers seeking to overcome obstacles with enlightened policies)', teachers represent 'themselves as the victims of flawed strategies with potentially disastrous consequences' 
(p. 122). Our case also supports the view in the FE literature (e.g. Ainley \& Bailey, 1997; Humphreys \& Hoque, 2007; Robson, 1998) that those who have experienced all the changes associated with the FE sector since incorporation are likely to express feelings of loss of autonomy and powerlessness. Looking to the future, there is research evidence that, in situations where senior managers ignore or attempt to coerce others into accepting their position, dis- satisfaction with the organization increases, and its capacity to function effectively is impaired (e.g. Humphreys \& Brown, 2002a, 2002b). This could have important implications for the future management of further education, a sector responsible for three-quarters of the UK's post-16 learners (Kerfoot \& Whitehead, 1998). Indeed, Goddard-Patel and Whitehead (2000) have argued that shortcomings in the management of the sector could have a considerable impact on UK skills formation, and subsequently on the competitiveness of the UK economy more generally.

\section{Conclusions}

Many well-known perspectives on emotions privilege an individualized perspective and have arguably suppressed flexibility in research approaches (see Fineman, 1993). New perspectives such as ours are called for which analyse emotions in the arenas in which they are felt and/or displayed. Others have indicated that wider collective sociocultural aspects of organizations are important for understanding claims about the stressfulness of work and psychological ill-being in the workplace (Barley \& Knight, 1992; Daniels et al., 2002; Ettner \& Grzywacz, 2001), but have not adopted a discursive approach. This research may, nevertheless, be regarded as part of a trend among recent studies to challenge conventional psychological analyses of emotions in organizations based on dualistic assumptions concerning self and situation (Briner et al., 2004; Dewe \& Trenberth, 2004; Lazarus, 1999). Our specific contribution has been to suggest, from an organizational and social perspective, that rules of appropriate emotional 
displays should be examined for the consequences of their relational, struc- tural, and institutional properties.

Our research also indicates that a thorough understanding of the discursive processes that constitute emotions in an organization is necessary to understand some of the barriers to improving work conditions (Dick, 2000; Harkness et al., 2005). We can relate this to research from other perspectives by considering whether rules constrain what we feel, by influencing how we construct and perform emotions. This might influence how we come to make judgements about the nature of job characteristics and work events (Daniels, 2006), thresholds between what is and is not accept- able, and how events will impinge on personal goals (Warr, 2006), well- being, or coping ability (Daniels et al., 2004), perhaps, influencing consequent emotions talk. That is, the rules that govern emotions might come to influence how we think about emotions, and subsequently what we feel, linking collective organizational or sub-organizational processes to individual cognitive processes in a direct way. This is an important area on which to focus attention if we wish better to understand the mutually constitutive relationship between emotional selves and organizational contexts.

\section{Note}

1 This mirrors Tracy's (2004) study of correctional officers who were working with the paradoxical organizational mandates to 'respect and nurture yet suspect and discipline' (2004: 530) which led to emotion displays of withdrawal, descriptions of 'paranoia' and constructions of 'us' and 'them' in interactions.

\section{References}

Ainley, P. \& Bailey, B. 1997. The business of learning: Staff and student experiences of further education in the 1990s. London: Cassell.

Albrow, M. 1994. Accounting for organizational feeling. In L. Ray \& M. Reed (Eds), New Weberian perspectives on work, organization 
and society. London: Routledge, , pp. 98-121.

Antaki, C., Billig, M., Edwards, D. and Potter, J. 2003. Discourse analysis means doing analysis: A critique of six analytical shortcomings. DAOL (Discourse Analysis On Line - electronic version), $, 1,1$.

Archer, M. 2000.Being human: The problem of agency. Cambridge: Cambridge University Press,

Armon-Jones, C. 1986.The thesis of constructionism. In R. Harré (Ed.), The social construction of emotions. Oxford: Basil Blackwell, pp. 32-56.

Ashforth, B. \& Humphrey, R. 1993. Emotional labor in service roles: The influence of identity. Academy of Management Review, 18, 88115.

Ashforth, B.E. \& Humphrey, R.H. Emotion in the workplace: A reappraisal.

Ashkanasy, N.M., Härtel, C.E.J. \& Zerbe, W.J. 2000. Emotions in the workplace: Research, theory and practice. Westport, CT: Quorum Books.

Baker, K. 1989. Further education: A new strategy. Address to ACFHE conference 15 February

Barbalet, J.M. 2001. Emotion, social theory, and social structure: A macrosociological approach. Cambridge: Cambridge University Press.

Barley, S.R. \& Knight, D.B. 1992. Toward a cultural theory of stress complaints. In B.M. Staw \& L.L. Cummings (Eds), Research in organizational behaviour, Vol. XIV. Greenwich, CT: JAI Press, pp. $1-48$.

Bedford, E. 1986. Emotions and statements about them. In R. Harré (Ed.), The social construction of emotions. Oxford: Basil Blackwell, pp. 15-31.

Bolton, S. 2000. Emotion here, emotion there, emotional organizations everywhere. Critical Perspectives on Accounting, 11, 155-71.

Bolton, S. 2003. Trolly dolly or skilled emotional manager: Moving on from Hochschild's managed heart. Work, Employment and Society, 17(2), 289-308.

Briner, R.B. 1999. The neglect and importance of emotion at work. European Journal of Work and Organizational Psychology, 8, 32346.

Briner, R.B., Harris, C. \& Daniels, K. 2004. How do stress and coping work? Toward a fundamental theoretical reappraisal. British 
Journal of Guidance and Counselling, 32, 223-34.

Brown, A.D. 2005. Deconstructing the Board of Banking Supervision's Report into the collapse of Barings Bank. Human Relations, 58(12), 1579-604.

Brown, A.D. \& Humphreys, M. 2003. Epic and tragic tales: Making sense of change. Journal of Applied Behavioral Science, 39(2), 12144.

Bruner, J. 1990. Acts of meaning. Cambridge, MA: Harvard University Press.

Burchill, F. 2001. The road to partnership? Forcing change in the UK further education sector; from 'college incorporation' and 'competition' to 'accommodation and compliance'? Employee Relations, 23, 146-63.

Callaghan, G. \& Thompson, P. 2002. We recruit attitude: The selection and shaping of routine call centre labour. Journal Management Studies, 39(2), 233-53.

Callahan, J.L. 2004. Reversing a conspicuous absence: Mindful inclusion of emotion in structuration theory. Human Relations, 57, 1427-48.

Clark, C. 1990. Emotions and micropolitics in everyday life: Some patterns and paradoxes of 'place'. In T.D. Kemper (Ed.), Research agendas in the sociology of emotions. Albany: State University of New York Press, pp. 305-34.

Coupland, C. 2001. Accounting for change: A discourse analysis of graduate trainees' talk of adjustment. Journal of Management Studies, 38(8), 1103-19.

Coupland, C. 2002. Discourse as data: A guide for analysis.

Review. Human Relations, 55(3), 360-9.

Craib, I. 1997. Social constructionism as a social psychosis.

Sociology, 31(1), 1-15.

Daniels, K. 2006. Rethinking job characteristics in work stress research. Human Relations,59, 267-90.

Daniels, K., Harris, C. \& Briner, R. 2002. Understanding the risks of stress: A cognitive approach.Sudbury: HSE Books,.

Daniels, K., Harris, C. \& Briner, R.B. 2004. Linking work conditions to unpleasant affect: Cognition, categorisation and goals. Journal of Occupational and Organizational Psychology, 77, 343-64.

Denzin, N. 1984. On understanding emotion. San Francisco, CA: Jossey-Bass.

Dewe, P. \& Trenberth, L. 2004. Work stress and coping: Drawing 
together research and practice. British Journal of Guidance and Counselling, , 32, 143-56.

Dick, P. 2000The social construction of the meaning of acute stressors: A qualitative study of the personal accounts of police officers using a stress counselling service. Work \& Stress, 14, 22644.

Domagalski, T.A. 1999. Emotion in organizations: Main currents. Human Relations, 52(6),833-52.

Doyle McCarthy, E. 1989. Emotions are social things: An essay in the sociology of emotions. In D. Franks \& E. Doyle McCarthy (Eds), The sociology of emotions: Original essays and research papers. Contemporary Studies in Sociology, Vol. 9. Greenwich, CT: JAI Press, pp. 51-72.

Edward, S., Coffield, F., Steer, F. \& Gregson, M. 2007. Endless change in the learning and skills sector: The impact on teaching staff. Journal of Vocational Education and Training, 59(2), 155-73.

Edwards, D. 1997. Discourse and cognition. London: SAGE.

Edwards, D. 1999. Emotion discourse. Culture and Psychology, 5(3), 271-91.

Edwards, D. 2001. Emotion. In M. Wetherell, S. Taylor and S.J. Yates (Eds), Discourse theory and practice: A reader. London: SAGE, pp. 236-46.

Ekman, P. \& Davidson, R.J. 1994. The nature of emotions: Fundamental questions. New York: Oxford University Press.

Ettner, S.L. \& Grzywacz, J.G. 2001. Workers' perceptions of how jobs affect health: A social ecological perspective. Journal of Occupational Health Psychology, 6, 101-13.

Fairclough, N. 1995. Critical discourse analysis: The critical study of language. London: Longman.

Fineman, S. 1993. Organizations as emotional arenas. In S. Fineman (Ed.), Emotion in organiz-ations. London: SAGE, pp. 9-31.

Fineman, S. 2000.Emotion in organizations, 2nd edn. London:

SAGE.

Fineman, S. \& Sturdy, A. 1999. The emotions of control: A qualitative exploration of environ- mental regulation. Human Relations, 52(5), 631-63.

Flam, H. 1993. Fear, loyalty and greedy organizations. In S. Fineman (Ed.), Emotion in organizations. London: SAGE, pp. 5875.

Gabriel, Y. 1995. The unmanaged organization: Stories, fantasies 
and subjectivity. Organization Studies, 16(3), 477-501.

Gabriel, Y. 2000.Storytelling in organizations. Oxford: Oxford University Press.

Goddard-Patel, P. \& Whitehead, S. 2000. Examining the crisis of further education: An analysis of 'failing' colleges and failing policies. Policy Studies, 21, 191-212.

Goddard-Patel, P. \& Whitehead, S. 2001. The mechanics of 'failure' in further education: The case of Bilston Community College. Policy Studies, 22, 181-95.

Goffman, E. 1959. The presentation of self in everyday life. New York. Doubleday,

Goffman, E. 1967. Interaction ritual: Essays in face-to-face behaviour. Chicago, IL: Aldine, Harkness, A.M.B., Long, B.C., Bermbach, N., Patterson, K., Jordan, S. \& Kahn, H. 2005. Talking about stress: Discourse analysis and implications for stress interventions. Work \& Stress, 19, 121-36.

Harré, R. 1986. An outline of the social constructionist viewpoint. In R. Harré (Ed.), The social construction of emotions. Oxford: Basil Blackwell, pp. 2-14.

Hearn, J. 1993. Emotive subjects: Organizational men, organizational masculinities and the (de)construction of emotions. In S. Fineman (Ed.), Emotion in organizations. London: SAGE, pp. 142-66.

Hepburn, A. \& Brown, S. 2001. Teacher stress and the management of accountability. Human Relations, 54, 691-716.

Hochschild, A.R. 1979. Emotion work, feeling rules and social structure. American Journal of Sociology, 85, 551-75.

Hochschild, A.R. 1983. The managed heart. Berkeley: University of California Press,.

Hochschild, A.R. 1993. Preface. In S. Fineman (Ed.), Emotion in organizations. London: SAGE, pp. ix-xiii.

Hopfl, H. \& Linstead, S. 1997, Learning to feel and feeling to learn: Emotion and learning in organizations. Management Learning, 28, 5-12.

Howard, C., Tuffin, K. \& Stephens, C. 2000. Unspeakable emotion: A discursive analysis of policetalk about reactions to trauma. Journal of Language and Social Psychology, 19(3), 295-314.

Humphreys, M. \& Brown, A.D. 2002a. Dress and identity: A Turkish case study. Journal of Management Studies, 39, 927-52.

Humphreys, M. \& Brown, A.D. 2002b. Narratives of 
organizational identity and identification: A case study of hegemony and resistance. Organization Studies, 39(3), 421-48.

Humphreys, M. \& Hoque, K. 2007. Have the lecturers lost their voice? Involvement and participation in the devolved Further Education sector. International Journal of Human Resource Management, 18(7), 1199-213.

Kerfoot, D. \& Whitehead, S. 1998. 'Boys own' stuff: Masculinity and the management of further education. Sociological Review, 3, 43657.

Kramer, M.W. \& Hess, J.A. 2002. Communication rules for the display of emotions in organizational settings. Management Communication Quarterly, 16, 66-81.

Lazarus, R.S. 1999. Stress and emotion: A new synthesis. New York: Springer.

Learmonth, M. 1999. The National Health Service manager, engineer and father? A deconstruction. Journal of Management Studies, 36, 999-1012.

Locke, A. 2002, Gendered emotion: Personal, cultural or discursive? Feminism and Psychology, 12, 97-104.

Lumby, J. 2003, Culture change: The case of sixth form and general further education colleges. Educational Management and Administration, 31, 159-74.

Lutz, C. 1996. Engendered emotion: Gender, power and the rhetoric of emotional control in American discourse. In R. Harré \& W.G. Parrott (Eds), The emotions: Social, cultural and biological dimensions. London: SAGE, pp. 151-70.

Lyotard, J.F. 1984. The postmodern condition: A report on knowledge. Minneapolis: University of Minnesota Press,

Merrill, B. \& Hyland, T. 2003.The changing face of further education. London: Routledge- Falmer.

Mills, A.J. \& Murgatroyd, S.J. 1991. Organizational rules: A framework for understanding organizational action. Milton Keynes: Open University Press,

Newton, T. 1995. 'Managing' stress: Emotion and power at work. London: SAGE.

Ortony, A., Clore, G.L. \& Collins, A. 1988. The cognitive structure of emotions. Cambridge: Cambridge University Press,

Patient, D., Lawrence, T.B. \& Maitlis, S. 2003. Understanding workplace envy through narrative fiction. Organization Studies, 24(7), 1015-44. 
Potter, J. 1996. Representing reality: Discourse, rhetoric and social construction. Los Angeles, CA: SAGE

Potter, J. \& Wetherell, M. 1987. Discourse and social psychology: Beyond attitudes and behaviour. London: SAGE.

Potter, J. \& Wetherell, M. 1988. Accomplishing attitudes: Fact and evaluation in racist discourse. Text, 8, 51-68.

Rafaeli, A. \& Sutton, R.I. 1989. The expression of emotion in organizational life. In L.L. Cummings \& B.M. Staw (Eds), Research in organizational behaviour, Vol. 11. Greenwich, CT: JAI Press, pp. $1-42$.

Robson, J. A 1998. Profession in crisis: Status, culture and identity in the further education college. Journal of Vocational Education and Training, 50, 585-607.

Sacks, H. 1992. Lectures on conversation. Oxford: Blackwell, Sarbin, T.R. 1986. Emotion and act: Roles and rhetoric. In R. Harré (Ed.), The social construction of emotions. Oxford: Basil Blackwell, pp. 83-97.

Sarbin, T.R. 1989. Emotions as narrative emplotments. In M.J. Packer \& R.B. Addison (Eds), Entering the circle: Hermeneutic investigation in psychology, pp. 185-201.

Schegloff, E.A. 1997. Whose text? Whose context? Discourse and Society, 8, 165-87.

Schegloff, E.A. 1998. Reply to Wetherell. Discourse and Society, 9, 413-16.

Shain, F. \& Gleeson, D. 1999. Under new management: Changing conceptions of teacher professionalism and policy in the further education sector. Journal of Education Policy, 14, 445-62.

Silverman, D. 1998. Harvey Sacks and conversation analysis. Cambridge: Polity Press.

Stenner, P. 2005. Rights or emotions, or: On the importance of having the right emotions. History and Philosophy of Psychology, , 7, 1-11.

Stokoe, E.H. and Smithson, J 2001. Making gender relevant: Conversation analysis and gender categories in interaction. Discourse and Society, 12, 217-44.

Strauss, A. 1959. Mirrors and masks. New York: Free Press. Sturdy, A. 2003. Knowing the unknowable? A discussion of methodological and theoretical issues in emotion research and organizational studies. Organization, 10, 81-105.

Sutton, R.I. 1991. Maintaining norms about expressed emotions: The case of bill collectors. Administrative Science Quarterly, 36, 245- 
68.

Tracy, S.J. 2004. The construction of correctional officers: Layers of emotionality behind bars. Qualitative Inquiry, 10(4), 509-33. Tseelon, E. 1991. The method is the message: On the meaning of methods as ideologies. Theory and Psychology, 1, 299-316. Van Dijk, T. 1997. Discourse as structure and process, Vol. 2. London: SAGE.

Vince, R. 2006. Being taken over: Managers' emotions and rationalizations during a company takeover. Journal of Management Studies, , 43, 343-65.

Wainwright, D. \& Calnan, M. 2002.Work stress: The making of a modern epidemic. Bucking- ham: Open University Press.

Waldron, V.R. 2000. Relational experiences and emotion at work. In S. Fineman (Ed.), Emotion in organizations, 2nd edn. London: SAGE, pp. 64-82.

Warr, P. 2006. Differential activations of judgments in employee well-being. Journal of Occupational and Organizational Psychology, 79, 225-44.

Watson, T.J. 2000. Discourse as organization. Human Relations, , 53(4), 559-73.

Wetherell, M. 1998. Positioning and interpretative repertoires:

Conversation analysis and post-structuralism in dialogue. Discourse and Society, 9, 387-412.

Widdicombe, S. 1998. Identity as an analysts' and a participants' resource. In C. Antaki \& S. Widdicombe (Eds), Identities in talk. London: SAGE, , pp. 191-206.

Williams, S.J. 2001. Emotion and social theory. London: SAGE.

Wittgenstein, L. 1953. Philosophical investigations. New York: Macmillan.

Zembylas, M. 2004. The emotional characteristics of teaching: An ethnographic study of one teacher. Teaching and Teacher Education, 20(2), 185-201.

Zembylas, M. 2005. Discursive practices, genealogies and emotional rules: A post-structuralist view on emotion and identity in teaching. Teaching and Teacher Education 21(8), 935-48. 